\title{
PENERAPAN MODEL CONNECTED MATHEMATIC PROJECT UNTUK MENINGKATAN KEMAMPUAN BERPIKIR KREATIF MATEMATIS SISWA MADRASAH ALIYAH
}

\author{
Nenden Suciyati Sartika1, Rusdian Rifa'í2
}

\begin{abstract}
This research is motivated by the low mathematical creative thinking of students of Aliyah Madrasah, so it is necessary to look for alternative learning that can improve mathematical creative thinking of Madrasah Aliyah students. The alternative learning applied is the connected mathematics project learning model. This study aims to find out (1) whether or not there is an increase in mathematical creative thinking skills of Madrasah Aliyah students; (2) Student activities during mathematics learning with the connected mathematics project Learning model. This research was conducted at the Aliyah Mathla'ul Anwar Madrasah Menes Center in the first semester of the 2017/2018 school year. The research method used is the quasi-experimental method. The population in the study was class XI Madrasah Aliyah Mathla'ul Anwar Pusat Menes Pandeglang District, while the sample was taken randomly from two classes from six classes in the school. Class XI Religion is an experimental class, namely a class that has learned to apply the connected mathematics project and class XI IPS as a control class, namely a class whose learning applies conventional learning. The research data was obtained by using the research instrument in the form of a question test instrument in a linear program material in the form of 5 questions. Question test data were analyzed by descriptive and inferential statistics using the average difference test. The results of the study show: (1) There is an increase in mathematical creative thinking skills using the connected mathematics project learning model; (2) Positive student activities during mathematics learning with the connected mathematics project learning model.
\end{abstract}

Keywords: Connected Mathematics Project, Mathematical Creative Thinking Ability

ABSTRAK: Penelitian ini dilatarbelakangi oleh rendahnya berpikir kreatif matematis siswa Madrasah Aliyah, sehingga perlu dicari alternatif pembelajaran yang dapat meningkatkan berpikir kreatif matematis siswa Madrasah Aliyah. Alternatif pembelajaran yang diterapkan adalah model pembelajaran connected mathematics project. Penelitian ini bertujuan untuk mengetahui (1) Ada tidaknya peningkatan kemampuan berpikir kreatif matematis siswa Madrasah Aliyah; (2) Aktifitas siswa selama pembelajaran matematika dengan model Pembelajaran connected mathematics project. Penelitian ini dilaksanakan di Madrasah Aliyah Mathla'ul Anwar Pusat Menes pada semester 1 tahun ajaran 2017/2018. Metode penelitian yang digunakan adalah metode kuasi eksperimen. Populasi dalam penelitian adalah kelas XI Madrasah Aliyah Mathla'ul Anwar Pusat Menes Kabupaten Pandeglang, sedangkan sampelnya diambil dua kelas secara acak dari enam kelas yang ada pada sekolah tersebut. Kelas XI Agama sebagai kelas ekperimen yaitu kelas yang pembelajarannya menerapkan connected mathematics project dan kelas XI IPS sebagai kelas kontrol

\footnotetext{
${ }^{1}$ Dosen Pendidikan Matematika, Universitas Mathla'ul Anwar Banten, Email: nendensuciyatisartika@gmail.com

2Dosen Pendidikan Matematika, Universitas Mathla'ul Anwar Banten, Email: rusdianrifai@gmail.com
} 
yaitu kelas yang pembelajarannya menerapkan pembelajaran konvensional. Data penelitian diperoleh dengan menggunakan instrumen penelitian berupa instrument tes soal pada materi program linear yang berbentuk soal essay sebanyak 5 soal. Data tes soal dianalisis dengan statistik deskriptif dan inferensial dengan menggunakan uji perbedaan rat-rata. Hasil penelitian menunjukan : (1) Terdapat peningkatan kemampuan berpikir kreatif matematis dengan menggunakan model pembelajaran connected mathematics project; (2) Aktifitas siswa positif selama pembelajaran matematika dengan model pembelajaran connected mathematics project.

Kata Kunci: Connected Mathematics Project, Kemampuan Berpikir Kreatif Matematis

\section{PENDAHULUAN}

Pendidikan merupakan salah satu upaya yang dilakukan pemerintah untuk meningkatkan kualitas sumber daya manusia. Melalui pendidikan pemerintah berupaya untuk mencerdaskan kehidupan bangsa dan mengembangkan manusia Indonesia. Pendidikan mempunyai peranan yang penting dalam mengembangkan diri untuk berprestasi secara utuh dalam kehidupan bermasyarakat. Pendidikan dasar bertujuan memberikan bekal kemampuan dasar pada siswa untuk mengembangkan kehidupan sebagai pribadi, anggota masyarakat, warga negara, dan umat manusia serta mempersiapkan siswa untuk mengikuti pendidikan dan mengembangkan sumberdaya manusia bertujuan agar mampu berperan dalam persaingan global, karena perkembangan ilmu pengetahuan dan teknologi terus mengalami perubahan disegala aspek kehidupan manusia. Salah satu cara untuk mendapatkan ilmu pengetahuan yaitu dengan cara belajar di sekolah formal. Banyak sekali ilmu pengetahuan yang diajarkan di sekolah formal melalui proses belajar mengajar sebagai contoh ilmu pengetahuan yang dipelajari di sekolah adalah matematika. Matematika dari tahun ketahun berkembang semakin meningkat sesuai dengan tuntutan zaman. Tuntutan zaman mendorong manusia untuk lebih kreatif dalam mengembangkan atau menerapkan matematika sebagai ilmu dasar.

Matematika adalah cabang ilmu pengetahuan yang amat mengharuskan setiap siswa memiliki kemampuan berpikir, dalam menghadapi tantangan zaman dan kemajuan teknologi. Walaupun peranan matematika sangat penting dalam setiap bidang kehidupan, namun harus diakui pula bahwa tidak semua orang dalam hal ini siswa menyukai matematika. Namun sampai saat ini mata pelajaran matematika termasuk mata pelajaran yang dianggap sulit dan menakutkan dibandingkan dengan mata pelajaran lain, sehingga matematika merupakan mata pelajaran yang kurang disenangi. Alasannya, mungkin karena harus bergelut dengan angka-angka dan rumus-rumus yang rumit, sehingga siswa kurang tertarik untuk menguasai matematika yang mengakibatkan rendahnya hasil belajar siswa dalam pelajaran matematika.

Matematika tumbuh dan berkembang karena proses berpikir. Menurut John Dewey (Sudarma, 2013: 38) berpikir adalah "stream of consciousness" arus kesadaran ini muncul dan hadir setiap hari, mengalir tanpa dikontrol, termasuk di dalamnya yaitu mimpi atau impian, dan lamunan. Hadirnya arus kesadaran tersebut, dapat dikategorikan pula sebagai bagian dari proses berpikir. Johnson dan Rising dalam buku Suherman bahwa matematika adalah pola berpikir, pola mengorganisasikan, pembuktian yang logik, matematika itu adalah bahasa yang menggunakan istilah yang didefinisikan dengan cermat, jelas dan akurat, representasinya dengan simbol dan padat, lebih berupa bahasa simbol mengenai ide dari pada mengenai bunyi 
(Suherman, 2001:19). Oleh karena itu, logika adalah dasar untuk terbentuknya matematika. Logika dari matematika, sebaliknya matematika adalah masa dewasa dari logika. Pada permulaannya cabang-cabang matematika yang ditemukan adalah berhitung atau aritmatika, geometri dan aljabar. Setelah ditemukan kalkulus yang sangat berfungsi sebagai tonggak penopang terbentuknya cabang matematika baru yang lebih kompleks, antara lain, aljabar, geometri, analisis vector statistika, topologi dan lain-lain.

Kemampuan berpikir adalah kemampuan satu keaktifan pribadi manusia yang mengakibatkan penemuan yang terarah kepada suatu tujuan. Kita berpikir untuk menemukan pemahaman atau pengertian yang kita kehendaki. Ciri-ciri yang utama dari berpikir adalah anggapan lepasnya kualitas atau relasi dari benda-benda, kejadian-kejadian dan situasi-situasi yang mula-mula dihadapi sebagai kenyataan. Berpikir kreatif sebagai suatu proses yang digunakan ketika seseorang mendatangkan atau memunculkan suatu gagasan baru. Gagasan baru tersebut merupakan gabungan gagasan-gagasan sebelumnya yang belum pernah diwujudkan. Menurut Hurlock kreativitas adalah suatu proses yang menghasilkan sesuatu yang baru, apakah suatu gagasan atau suatu objek dalam suatu bentuk atau susunan yang baru (Sudarma, 2013:18). Maka dapat disimpulkan berpikir kreatif merupakan kemampuan berpikir kita untuk menemukan sesuatu yang baru, gagasan baru maupun menciptakan suatu gagasan yang baru. Berpikir kreatif matematis dalam matematika sangat penting untuk ditumbuhkembangkan dalam pembelajaran kepada peserta didik, khususnya dalam pembelajaran matematika dengan memilih suatu model atau pendekatan pembelajaran tepat, sehingga dapat membangkitkan kemampuan berpikir kreatif matematis siswa.

Salah satu pengajaran yang kurang mengembangkan kemampuan berpikir kreatif matematis siswa, peneliti temui pada saat obsrvasi salah satu sekolah yang berada di Sekolah Madrasah Aliyah Mathla'ul Anwar Pusat Menes. Berdasarkan hasil observasi di Madrasah Aliyah Mathla'ul Anwar Pusat Menes, dalam satu ruangan kelas XI IPS berjumlah 28 siswa dan memiliki nilai di bawah rata- rata yaitu 70 , namun perlu ditingkatkan kembali. Ini dapat dilihat materi peluang dengan memberikan soal uraian yang menekankan pada kemampuan berpikir kreatif matematis siswa, sebagian besar siswa tidak dapat menyelesaikan soal uraian tersebut dengan baik dan benar. Penyebabnya yaitu kurangnya keinginan siswa membaca, memahami dan melatih kembali pelajaran yang telah disampaikan, Selain matematika yang dianggap sukar oleh siswa, faktor metode pengajaran berpengaruh terhadap hasil belajar matematika siswa. Terlihat dari belajar matematika siswa yang kurang memuaskan, walaupun tidak semua siswa yang mendapatkan hasil belajar matematika yang kurang memuaskan dan juga tidak adanya variasi model pembelajaran yang dilakukan oleh guru serta media pembelajaran yang tersedia pun masih dirasakan kurang, yang pada akhirnya siswa merasa jenuh atau bosan selama kegiatan belajar mengajar berlangsung di kelas dan akan menghambat kegiatan belajar mengajar. Kondisi seperti ini dapat dilihat dari banyaknya siswa mendapatkan nilai rendah pada mata pelajaran ini disebabkan karena kurangnya aktivitas siswa berpartisipasi dalam mengikuti kegiatan belajar mengajar dan pada akhirnya siswa mengalami kesulitan dalam belajar terutama pada kemampuan berpikir kreatif matematis.

Untuk meningkatkan kemampuan berpikir kreatif siswa, sebaiknya guru dapat memotivasi belajar siswa dan menciptakan kondisi belajar mengajar yang efektif. Motivasi belajar yang dilakukan oleh guru dalam proses belajar mengajar amatlah 
penting, karena dengan adanya motivasi yang sangat besar pada diri siswa dengan keingintahuan siswa terhadap materi yang diberikan oleh guru, maka akan terciptanya proses belajar mengajar yang baik dan menjadi awal tercapainya hasil belajar yang memuaskan. Kondisi belajar mengajar yang efektif, dapat dilakukan oleh guru dengan cara memberi kesempatan belajar kepada siswa yang melibatkan siswa secara aktif dalam belajar. Makin banyak siswa yang aktif, makin tinggi kemungkinan hasil belajar yang dicapai. Hal ini merupakan ciri dari pembelajaran yang berpusat pada siswa. Belajar matematika konstuktivisme adalah proses dimana guru dan siswa terikat dalam pembelajaran yang bermakna.

Sarana dan prasarana penunjang kegiatan belajar juga berpengaruh terhadap keberhasilan pembelajaran matematika. Bermacam peralatan dapat digunakan oleh guru untuk menyampaikan materi pelajaran kepada siswa melalui penglihatan dan pendengaran untuk menghindari verbalisme yang masih mungkin terjadi kalau hanya digunakan alat bantu visual semata sebagai sumber belajar. Alat-alat tersebut kita kenal sebagai media pembelajaran. Media diharapkan dapat membantu guru dalam mengurangi keterbatasan sumber guru yang ada, sehingga dalam media pembelajaran dapat membantu guru dalam menyampaikan materi kepada siswa. Oleh karena itu, strategi pembelajaran matematika harus diorientasikan kepada siswa, sehingga interaksi yang terjadi dalam proses belajar mengajar dapat berjalan sesuai dengan yang diharapkan, karena pola pengajaran yang berpusat pada siswa ialah siswa turut berperan aktif dalam kegiatan belajar mengajar baik itu fisik, emosional, mental, spiritual dan kecerdasan intelektual.

Menyadari akan pentingnya kemampuan berpikir kreatif pembelajaran mengupayakan dengan menggunakan pendekatan atau model yang memberikan peluang atau mendorong untuk melatih kemampuan berpikir kreatif. Dalam hal ini, salah satu atau alternatif agar membantu menumbuhkembangkan kemampuan berpikir kreatif yaitu dengan model pembelajaran connected mathematics project. Model pembelajaran connected mathematics project memberikan pengetahuan seluas-luasnya untuk membangun pengetahuan matematiknya sendiri, model pembelajaran connected mathematics project bertujuan untuk membantu siswa dan guru mengembangkan pengetahuan matematika pemahaman dan keterampilan berpikir. Model pembelajaran connected mathematics project menumbuhkan siswa untuk berdiskusi secara efektif tentang masalah-masalah yang diberikan dan dapat menstimulasi mengembangkan kemampuan berpikir kreatif matematis siswa dalam menyelesaikan setiap variasi masalah.

\section{METODE PENELITIAN}

Jenis penelitian yang dilakukan adalah penelitian true experimental karena dengan metode ini, peneliti dapat mengkontrol semua variabel luar yang mempengaruhi jalannya eksperimen (Sugiyono, 2011: 112). Data yang diperoleh lalu diolah, ditafsirkan dan disimpulkan. Data yang diperoleh dalam penelitian ini adalah data kuantitatif. Data kuantitatif yaitu dapat diartikan sebagi metode penelitian yang berlandasakan pada filsafat positivisme, digunakan untuk meneliti pada populasi atau sampel tertentu, teknik pengamabilan sampel pada umumnya dilakukan secara random, pengumpulan data menggunakan instrumen penelitian, analisis bersifat kuantitatif atau statistik dengan tujuan untuk menguji hipotesis yang telah diterapkan.

Terdapat dua variabel dalam penelitian ini yaitu kemampuan berpikir kreatif matematis siswa yang bertindak sebagai variabel terikat dan model pembelajaran 
connected mathematics project (CMP) sebagai variabel bebas. Desain penelitian ini yang digunakan adalah subyek random design pretest-postest grup (Randomized subject, pretest-postes control grup design).

Tabel 1. Desain Penelitian

\begin{tabular}{cccc}
\hline Group & Pre test & Treatment & Post test \\
\hline ®Ekspeiment & $\left(\mathrm{Y}_{1}\right)$ & $\mathrm{X}$ & $\left(\mathrm{Y}_{2}\right)$ \\
®Kontrol & $\left(\mathrm{Y}_{1}\right)$ & & $\left(\mathrm{Y}_{2}\right)$ \\
\hline
\end{tabular}

(Sugiyono, 2011: 112)

Keterangan:

$\mathrm{Y}_{1}$ : Pre Test

$\mathrm{Y}_{2}$ : Post Test

$\mathrm{X}$ : Pembelajaran matematika dengan model pembelajaran CMP.

\section{HASIL DAN PEMBAHASAN}

Data prestasi belajar diperoleh dari kelas eksperimen yang berjumlah 28 siswa dan kelas kontrol yang berjumlah 28 siswa, kemudian kedua kelas diberikan soal pretes dan postes. Data hasil pretes dan postes dihitung dan diperoleh hasil sebagai berikut. Gambaran mengenai skor pretes baik untuk kelas eksperimen maupun untuk kelas kontrol seperti pada Tabel 2 berikut.

Tabel 2. Data Hasil Pretes

\begin{tabular}{ccccccc}
\hline $\begin{array}{c}\text { Kelompok } \\
\text { Kelas }\end{array}$ & $\mathrm{N}$ & $\bar{X}$ & $\mathrm{~S}$ & $\mathrm{~S}^{2}$ & $\begin{array}{c}\text { Nilai } \\
\text { Terendah }\end{array}$ & $\begin{array}{c}\text { Nilai } \\
\text { Tertinggi }\end{array}$ \\
\hline Eksperimen & 28 & 18.57 & 8,18 & 66,91 & 3 & 36 \\
Kontrol & 28 & 17.28 & 9,58 & 91,77 & 3 & 35 \\
\hline
\end{tabular}

Dari Tabel 2 terlihat bahwa kemampuan berpikir kreatif siswa kelas eksperimen memperoleh nilai rata-rata pretes 18,57 , sedangkan kelas kontrol memperoleh nilai rata-rata pretes 17,28 . Gambaran mengenai skor postes baik untuk kelas eksperimen maupun untuk kelas control seperti pada Tabel 3 berikut.

Tabel 3. Data Hasil Postes

\begin{tabular}{ccccccc}
\hline $\begin{array}{c}\text { Kelompok } \\
\text { Kelas }\end{array}$ & $\mathrm{N}$ & $\bar{X}$ & $\mathrm{~S}$ & $\mathrm{~S}^{2}$ & $\begin{array}{c}\text { Nilai } \\
\text { Terendah }\end{array}$ & $\begin{array}{c}\text { Nilai } \\
\text { Tertinggi }\end{array}$ \\
\hline Eksperimen & 28 & 50.64 & 14.47 & 209,38 & 28 & 80 \\
Kontrol & 28 & 37.64 & 15.47 & 239,23 & 15 & 68
\end{tabular}

Dari Tabel 3 terlihat bahwa kemampuan berpikir kreatif siswa kelas eksperimen dengan menggunakan model pembelajaran connected mathematics project diperoleh nilai rata-rata postes 50.64, sedangkan kelompok kelas kontrol dengan menggunakan pembelajaran konvensional diperoleh nilai rata-rata postes 37,64. Berdasarkan nilai rata-rata, maka pada kelas yang pembelajarannya menggunakan pembelajaran connected mathematics project mempunyai nilai rata-rata yang lebih 
besar daripada kelas yang pembelajarannya menggunakan pembelajaran konvensional.

Gain dilakukan untuk mengetahui peningkatan kemampuan kedua kelas setelah diberi perlakuan yang berbeda, apakah kemampuan berpikir kreatif matematika kelas eksperimen lebih baik daripada kemampuan berpikir kreatif kelas kontrol. Setelah dilakukan pengolahan data postes maka didapat nilai rata-rata, standar deviasi (s) dan varians $\left(\mathrm{s}^{2}\right)$.

Tabel 4. Data Gain

\begin{tabular}{cccc}
\hline Kelas & Rata-Rata & Varians $\left(\mathrm{s}^{2}\right)$ & Standar Deviasi (s) \\
\hline Eksperimen & 0.40 & 0.026 & 0,16 \\
Kontrol & 0.25 & 0.021 & 0.14 \\
\hline
\end{tabular}

Dari Tabel 4 terlihat bahwa kelas eksperimen memperoleh nilai rata-rata 0,40, sedangkan kelompok kelas kontrol memperoleh nilai rata-rata 0,25. Berdasarkan nilai rata-rata gain, maka kelas eksperimen mempunyai nilai rata-rata yang lebih besar daripada kelas kontrol.

Seorang guru perlu memikirkan jalan agar setiap murid mendapatkan bimbingan agar ia berhasil menyelesaikan pelajarannya dengan baik serta menguasai bahan pelajaran secara tuntas. Oleh karena itu, kemampuan guru dalam menyampaikan materi dan penguasaan materi merupakan modal dalam kelangsungan proses pembelajaran. Model pemebelajaran connected mathematics project dalam pembelajaran matematika yang menuntut siswa agar dapat memecahkan suatu masalah, dan juga dapat mengembangkan kemampuan berpikir kreatif matematikanya sendiri, untuk menemukan caranya sendiri dalam memecahkan masalah. Dengan kata lain model pembelajaran dengan connected mathematics project,t siswa dikatakan belajar ketika siswa membangun pengetahuannya sendiri. Dalam model pembelajaran connected mathematics project mengikuti teori konstruktivisme yang menyatakan bahwa seorang guru tidak mengajarkan kepada anak bagaimana menyelesaikan persoalan, namun mempresentasikan masalah dan mendorong siswa untuk menemukan cara mereka sendiri dalam menyelesaikan permasalahan.

Dengan model pembelajaran connected mathematics project, siswa dapat membangun ilmu pengetahuan melalui kemampuan berpikir kreatif yang diberikan oleh guru sesuai dengan materi yang sedang dibahas. Hal ini dapat meningkatkan minat belajar matematika siswa, dapat meningkatkan aktifitas siswa dalam proses pembelajaran dan mengakibatkan pada hasil belajar matematika siswa yang memuaskan. Hasil penelitian yang dilakukan di Madrasah Aliyah Mathla'ul Anwar Pusat Menes ini menyimpulkan bahwa terdapat perbedaan kemampuan berpikir kreatif matematika siswa yang mendapat pembelajaran melalui model pembelajaran connected mathematics project dengan pembelajaran konvensional. Dimana kemampuan berpikir kreatif matematika siswa yang mendapat pembelajaran dengan menggunakan model pembelajaran connected mathematics project lebih baik dibandingkan kemampuan berpikir kreatif matematika siswa yang mendapat pembelajaran dengan menggunakan pembelajaran konvensional.

Sebelum pembelajaran dilakukan pada kedua kelas, diketahui bahwa kemampuan awal kelas eksperimen dan kelas kontrol adalah sama. Namun setelah dilakukannya pembelajaran matematika pada kelas eksperimen yaitu kelas XI Agama 
yang menggunakan model pembelajaran connected mathematics project dan kelas kontrol yaitu kelas XI IPS yang menggunakan pembelajaran konvensional, hasilnya siswa yang belajar dengan menggunakan model pembelajaran connected mathematics project memiliki kemampuan berpikir kreatif matematika yang lebih baik dibandingkan siswa yang belajar dengan menggunakan pembelajaran konvensional.

Kedua kelas mengalami peningkatan kemampuan berpikir kreatif, hal ini dapat dilihat dari hasil rata-rata sebelum dan sesudah pembelajaran. Kelas eksperimen pada tes awal (pretes) mendapat rata-rata 18,57 dan tes akhir (postes) mendapat rata-rata 50.64, sehingga dari rata-rata tes awal dan tes akhir terdapat kenaikan 32,07 . Kelas kontrol pada tes awal mendapat rata-rata 17.28 dan tes akhir mendapat rata-rata 37.64, sehingga dari rata-rata tes awal dan tes akhir terdapat kenaikan 20,36. Kemudian setelah diuji dengan uji-t pada taraf signifikan $5 \%$ hasilnya siswa yang belajar dengan menggunakan model pembelajaran connected mathematics project secara signifikan memiliki kemampuan berpikir kreatif matematika yang lebih baik dibandingkan siswa yang belajar dengan menggunakan pemebalajaran konvensional atau dengan kata lain pembelajaran dengan model pembelajaran connected mathematics project memberikan peningkatan yang signifikan terhadap kemampuan berpikir kreatif matematika siswa Madrasah Aliyah Mathla'ul Anwar Pusat Menes.

Selain menggunakan tes, peneliti juga melakukan wawancara bebas terhadap siswa tentang model pembelajaran connected mathematics project dan pembelajaran konvensional. Pendapat siswa tentang model pembelajaran connected mathematics project ini sangat menyenangkan dan tidak membosankan, siswa merasa lebih memahami materi yang diberikan guru dengan memberikan contoh-contoh soal yang berkaitan dengan kehidupan mereka sehari-hari. Pendapat siswa tentang pembelajaran konvensional sangat menyenangkan dan sedikit menegangkan, karena siswa merasa pada pembelajaran konvensional dituntut agar bahan ajar dikuasai secara tuntas sekurang-kurangnya memenuhi standar ketuntasan belajar minimum dan membuat siswa selalu belajar walaupun tidak ada PR.

Model pembelajaran connected mathematics project terdiri dari tiga langkah, yaitu lauching, exploring dan summarizing. Pada awal pertemuan siswa masih beradaptasi dengan pembelajaran matematika dengan menggunakan model pembelajaran connected mathematics project, namun siswa menerimanya dengan antusias. Hal ini disebabkan pembelajaran seperti ini merupakan hal yang baru bagi siswa dan siswa bebas mengemukakan pendapat. Pada langkah kedua, yaitu kerja kelompok, pada langkah ini siswa sangat aktif dalam kerja kelompok, setiap kelompok mendiskusikan hasil kerjanya masing-masing pada kelompok tersebut. Siswa saling bernegosiasi dengan siswa yang lain maupun guru, tahapan kerja kelompok berjalan dengan lancar. Namun ada siswa yang merasa tidak nyaman dengan belajar kelompok, yang disebabkan teman satu kelompok hanya menggangu tidak membantu dalam memecahkan permasalahan.

\section{KESIMPULAN}

Berdasarkan pengujian hipotesis dan hasil penelitian di Madrasah Aliyah Mathla'ul Anwar Pusat Menes dapat disimpulkan Model pembelajaran connected mathematics project dapat meningkatkan terhadap kemampuan berpikir kreatif matematis siswa. Hal ini terlihat dari berpikir kreatif siswa yang memperoleh pembelajaran matematika dengan model pembelajaran connected mathematics project lebih baik daripada berpikir kreatif siswa yang memperoleh pembelajaran 
kovensional. Berdasarkan hasil observasi terlihat bahwa aktifitas siswa selama pembelajaran matematika dengan model pembelajaran connected mathematics project siswa merespon positif. Dapat disimpulkan aktifitas siswa positif terhadap pembelajaran matematika menggunakan model pembelajaran connected mathematics project.

\section{DAFTAR PUSTAKA}

Sudarma, M. (2013). Mengembangkan Keterampilan Berfikir Kreatif. Jakarta: Rajawali.

Sugiyono. (2011). Metode Penelitian Pendidikan. Bandung: Alfabeta.

Suherman, E. (2001). Strategi Pembelajaran Matematika Kontemporer. Bandung: JICA Universitas Pendidikan Indonesia (UPI). 